\title{
Attracting Chinese Foreign Direct Investment (FDI) to Africa: Determinants and Policies - The Case of Guinea
}

\author{
Diallo Mamadou Saliou Kokouma ${ }^{1} \&$ Kaning $\mathrm{Xu}^{2}$ \\ ${ }^{1}$ School of Economic and Management (International Trade), Southeast University, Nanjing, China \\ ${ }^{2}$ School of Economic and Management, Southeast University, Nanjing, China \\ Correspondence: Diallo Mamadou Saliou Kokouma, School of Economic and Management (International Trade), \\ Southeast University, No.2 Sipailou, Nanjing 210096, China. E-mail: salitadiallo@yahoo.ca
}

Received: October 26, 2012

Accepted: March 12, 2013

Online Published: October 8, 2013

doi:10.5430/ijfr.v4n4p52

URL: http://dx.doi.org/10.5430/ijfr.v4n4p52

\begin{abstract}
This study examines the determinants and policies for attracting Chinese FDI to Africa by specifically analyzing major characteristics, trends and developments in the economic engagement between Guinea and China. Guinea's selection as the case study is justified by the country's experience of macroeconomic instability and social policy since independence. By considering mechanisms that play important roles in attracting FDI; market size, economic growth, employment, degree of trade openness and trade policy of the recipient country, the results show positive R-squared- a valid regression. However, all of these coefficients of determination are still not significant enough. The disparity to attract investment is assessed from geographical location, infrastructure, corruption levels, and income yields to implementation of the policies by the governments. It recommends policies at both national and bilateral levels in order to increase large Chinese FDI inflows towards Guinea and improve the forecast for macroeconomic and its constant development.
\end{abstract}

Keywords: FDI, China-Guinea, determinants, policies, developing countries

\section{Introduction}

Cooperation between China and Guinea dates back more than 40 years, more precisely 4 October 1959. Since that time, it has allowed the realization of many actions which have contributed significantly to the socio-economic development of Guinea. This cooperation with the dominant feature is its disinterested character, was conducted primarily through interest-free loans, grants and non-repayable financial donations in kind (food, pharmaceuticals etc ...). Loans and grants have enabled many projects in the following areas: agriculture, industry, crafts, infrastructure, energy, telecommunications; health; technical, private, and in international business fields and has also an important part of military assistance. In 2003, China became the main trading partner of Guinea after France. China has been providing cheap manufactured goods to Guinea and the latter has reduced dependence on its traditional trading partners. Flows of FDI from China to Guinea also grew rapidly, although their volumes are now lower than those of imports of goods and services. In the medium term, China plans to finance the construction of a 750 megawatt hydroelectric dam in Guinea. In return, Guinean authorities in Beijing will ensure opportunity to approach mineral resources comparable around two billion tones of bauxite, the raw material from which aluminum is derived.

Although relations between China and Guinea are the subject of increasing attention, there is much less research on these relationships. While research is conducted, they are very rare and unpublished. Most claims about the relations between China and Guinea are then based on assumptions made by the press rather than empirical evidence. The main objective of this report is to assess the size, structure and significance of relations between the two countries. These relationships cover trade, investment and development assistance among others. And to examine the key policies determinants for attracting Chinese FDI towards Guinea.

The rest of this paper is divided into five parts- the next part lays out a review of the available literature on the topic and discusses various theories related to the major determinant of FDI from different perspectives and empirical studies. It will also attempt to answer the question on why African countries are different in attracting FDI. Part three reviews FDI trends in Guinea and analyzes market opportunities for Chinese FDI-seeking firms in the country by examining the possibilities for investment in different sectors as well as the policy background for Guinea FDI. In part four is discussing the data and methodology used in empirical analysis and at the same time presents the results and demonstrating the general way for performing the Chinese FDI in Guinea; by using Statistical Package for the Social 
Sciences (SPSS) for data analysis and comparative analysis of Chinese OFDI Stocks in Top West African Region. Finally, part five to complete with a summary and some suggestions for policies needed to attract more Chinese FDI in Guinea.

\section{Literature Review}

Various researches on FDI shows a perfect harmony between the different economic structures and the behavior of economic agents, both in terms of economic aggregates and households levels, making allowance for a fresh fields of study in the literature. This section aims to investigate the fundamental motivations, why the large multinational companies invest abroad in foreign markets rather than improving domestic production in their local markets. The review will also distinguish African countries by arguing that FDI to sub-Saharan Africa (SSA) is driven by different factors, and will explain why the success of the program in other countries is not the same in another, such as SSA.

\subsection{Empirical Studies on FDI}

A substantial amount of literature and various theories attempt to explain the determinants of FDI, focusing on both developed and developing nations (Guinea in particular), supported by recent empirical studies. This study seeks to isolate and compare countries location as an attraction for FDI in the manufacturing sectors. It is very frequent in the literature on the determinants of FDI before any investment in abroad; the multinational companies (MNC) examine factors for information of the field, compared to the pay scale of employees and the performance of the labor, capital costs and the size of the market and its accessibility (Biswas, 2002).

Of all the basic determinants of FDI, the most important are the size of the market, which is a fundamental requirement before any investment (Agarwal, 1980). According to Ramasamy and Yeung (2010), they note that it is normal to assume that the level of the market value and purchase high is a great asset to attract more investors and FDI. This relationship can be explained by the reduced cost of entry at the economic scale to be used in part by other broader market. And in another hand an increase in the purchasing power helps differentiate products instead of causing localization of the product / service. FDI is a long term investment, but also an improvement in living conditions of the population in countries that receive these multinational investors. Variables of the macro and micro were examined in the literature to cover all the factors involved in the game.

The other factor that determines important traditional FDI is that comparative advantage costs. According to (Lall et al 2003) argue that the effectiveness of FDI depends on factors that are generally relatively low cost of labor, qualification according to market demand and transportation costs, which are essential for an environment conducive to FDI both long term and short term. According to (Bellack et al 2008) in their studies of empirical literature that explains the abundance of well-educated workforce with a cheap salary causes a large influx of FDI into the country. In other hand maximizes the strengths they possess and adapt to the local environment using local talent. This would allow them to expand their market, not only in the host country but also in the sub-region. And also Feenstra and Hanson (1997) in their analysis in the case of Mexico, they did find a significant relationship between the growth of FDI and the relative demand for qualified workforce. However, in developing countries, the low salary with a poorly trained staff may impede the flow of FDI in renowned international corporations (Ramasamy and Yeung 2010).

According to (Coughlan et al., 1991, Cheng and Kwan 2000 and Ramasamy and Yeung 2010) they conclude in their studies a significant correlation between the reliability of the infrastructure in a country as an important asset for attracting FDI. Asiedu (2002) noted that the development of infrastructure and the cost of capital and interest elements are helping with the influx of FDI mostly in the northern countries, but not evident in sub-Saharan Africa. Given that an investment agreement of donors to a host country, a very exorbitant profit can influence the trend and dangerously affect the extent of FDI flows. When to Moshirian (1997) found against performance between interest rates and long-term FDI inflows. This while, according to Alfaro et al (2009) improving the financial system of a country could encourage the management of host economies for FDI more beneficial as it is associated with financial development. The most important factor is the cost of agglomeration economies. Costs of feasibility and costs of expert study of the project before its implementation affect heavily on investors during the first phase and sometimes foreign companies are forced to use other related industries. FDI involves a lot of risk in their investment policies outside. According to Krugman (1997) articulated that political instability and bad governance in a country, causes uncertainty among domestic investors, it can have a strong signal against multinational investors in the reliability of the location of host country. Guimaraes et al (2000) have proven that cities can be considered as a major determinant of FDI flows. Barry et al (2001) reported the same as their predecessor's launch the business location is also a factor favoring the return of FDI is considered a mark of reliability in a host country.

For investors, economic stability is essential for any investment in a country. Vijayakumar et al (2010) consider that when an economy has inflation as reference for its economic stability, control fiscal and monetary inflation it will cause unrestrained. Currency depreciation in a country is very significant for macroeconomic stability. Exchange devaluation is due to a lower cost of production and assets of foreign investors and promotes increased influx of 
multinational in the country. According to (Froot and Stein, 1991, Kiyota and Utara, 2004) their empirical studies have proven that the depreciation can attract more FDI, while a high volatility of the exchange rate demoralizes investors.

All spending has a positive or negative effect on the decision to locate or not a private company in a country. According to (Coughlin et al.1991) argue that, given public spending at certain area, such as education and infrastructure could affect FDI. And a government that simply by providing information and incentives can encourage the inflow of FDI in a country. In their study tour report to the K-Park in Wuxi, the International Business Class of 2010 at Southeast University noted the various incentives, ranging from free office blocks to manpower identification that have been provided by both the Wuxi Local Government and Chinese Central government in order to attract global investors such as IBM and Oracle to set up their Resource and Development (R\&D) centers. Luger and Shetty (1985) and Coughlin et al $(1990,1991)$ agree that public spending has a positive effect oriented towards the promotion of FDI. Another element of the determinant of FDI is trade policy by Balasubramanyam et al (1996) argue that FDI is more beneficial for a country that has opened trade policy oriented outward relative to the oriented inside. By Konishi et al (1999) listed only with blockade at the level of the trade that can curb the inflow of FDI to local markets.

Biswas (2002) in his observations showed that most studies on their traditional determinants regression coefficient usually vary from 0.30 to 0.55 which does not really mean to appreciate the regression. This can promote the failure to include non-traditional factors which in turn affected the attendance and the nature of FDI in the country. According to Addison and Heshmati (2003) have shown that the invention and adoption of new technologies have revitalized the inflow of FDI into the country. Taking into account the recent revolutions, new technologies of information and communication (ICTs) have played a large role in changing global sectors such as manufacturing and services that have become as measure for developing countries. Since the advent of democracy in 1980 with the opening of political systems and good governance have become the catalysts for economic reforms and promotion of foreign investment. These criteria mentioned above include, the technological communication and democratization as interacting to redevelop the commercial capital flows, including FDI.

During the 90s, the literature of political and institutional determinants of FDI is the topics most frequently discussed by researchers. Whereas strong institutions and good governance are essential in the strategy to attract foreign investment and also in improving productivity. Indeed, contrary to all political strategy that would expose the country to the unreliability of these institutions. Consequently, factors that are promoting additional costs to the FDI will be very vulnerable to any kind of event including the instability of government canceled contracts previously signed and the weak enforcement of property rights and flawed legal system (Quere et al, 2007). According to (Busse and Hefeker, 2007 and Frey \& Schneider 1985) argue that all political risk in a country has its quota of uncertainty which could affect either political institution with unexpected changes in the "rules of the game" in bilateral and multilateral agreements and the same time the attitudes of multinational investors. On the other hand, it can reduce FDI inflows; causing additional expenses as the risk premium embedded in investment projects and the uncertainty in the implementation of the Project. But (Bevan and Estrin, 2004) Noted that the analysis of transitional economies considered as a determinant of FDI is insignificant risk of the recipient country. However, Kolstad and Villanger (2007) replicate the capacity of institutions and democratic alternation are more important as determinants of political instability.

All indicators of diplomatic ties are significant as well since Chinese aid, like that of the traditional donors (see Alesina and Dollar 2000), is closely related to political relationship. And we observe a bias towards small countries, as is pointed out in the analyses of DAC donors' aid. Two negative results should be highlighted- the coefficient on per capita GDP is not significant, and while China's engagement in Africa (unlike that of traditional donors-see e.g. Berthelemy 2006) is usually described as focused on countries with governance issues, none of the governance indicators' coefficients were significant (result not reported).

\subsection{Uniqueness of African Countries}

According Asiedu (2002) in this research, it is focused on the empirical analysis with a data set comprising 71 developing countries which are more than half the countries of sub-Saharan Africa. He also noted in its analysis about the importance of study of FDI flows to Africa, due to the scarcity of related topics and its contribution to the growth of the region. However, it would be normal to emphasize that this growth factor in the case of the African region is still very slow or absent. This can be explained by the fact that FDI flow to Sub-Saharan Africa is highly dependent on various socio-economic and development policies. For this reason, each nation's policies and development strategy affects the success of its growth.

In summarizing his results, Asiedu (2002) noted that according to the research the average FDI received in SSA is below normal of other countries in the sub-region because of its geographical location or culture. However, the abundance of capital and the development of infrastructure increase the influence FDI for non-sub-Saharan countries 
but no remarkable effect on the inflow of FDI to Africa and trade openness has a positive impact on FDI flows to all regions.

However, the success of FDI in sub-Saharan Africa is less attractive as compared to the change observed in the openness of FDI to other regions. Thus, the results presented above show that Africa is different. On the other hand, Godspeeds et al (2006) in their study of regression analysis noted the lower taxes, fight against corruption and the development of basic infrastructure are means to attract more FDI to countries. While better balanced strategy in providing infrastructure in a country seems to have more long-term benefit and more success in promoting and encouraging FDI in a country than a relative simple reduction of state taxes or reduce corruption.

Therefore, the literature discussing the attraction of FDI and its opinions converge when the point is related to Africa. Kebonang and Mosweu; noted that the crisis of confidence among investors and African countries are caused by: political instability, non-compliance with commitments in power, inability to protect investors and their property, the lack of human rights and lack of alternation of political power. These are the reasons why investors are hesitant to make long-term commitments in Africa. However, as reforms in Africa are often dependent on financial assistance from donors, so this is the formula of reforms accompanied with aid. This dilemma has caused uncertainty among multinational to interrupt their long-term investments or change some rule of investment in other areas.

\section{FDI Trends in Guinea}

Despite Guinea's first free and independence in Africa, in originally only sectors are allowed on FDI was mining and energy; but later the agricultural sector has been requested.

According to the report (March 2011), Bureau of Economic, Energy and Business Affairs; statistics on FDI are difficult to obtain, but during the second administration Guinea began to open its economy to FDI in the 1980s and was one of the beneficiaries of FDI with developing countries, especially that from China in1990s, because of regional stability, improving economic management and external market factors.

FDI flows to Guinea remained very low until the 1990s; (see Figure 1) an average of $\$ 2.2$ million for the period 1980 -1990. Since 1990, they began to increase as agreed with the reform program and privatizations have continued to improve good records for the past few years, an average of \$101,350,000 million in 1999-2010.

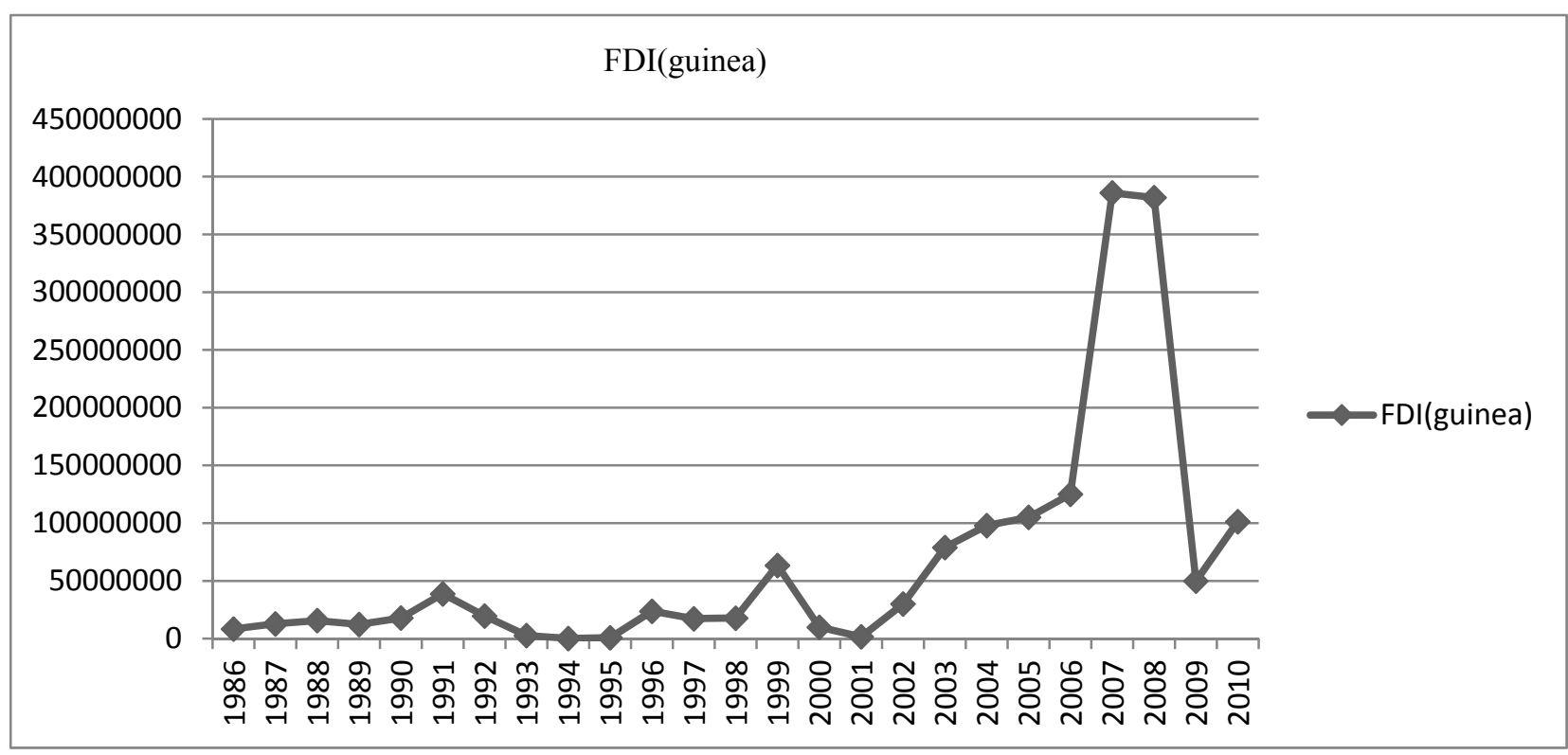

Figure 1. FDI inflow to Guinea, 1986-2010

Source: World Bank and Yearbook

With the reform program in 1992, investment policies in Guinea is simplified by the Office for the Promotion of Private Investment (OPIP) were liberalized to allow private companies in almost all sectors. TNCs have played an important role in Guinea economic progress through following of cross-border mergers and acquisitions (M\&A) related to the privatization program. In particular, the investment taking place across all major sector: mining telecommunications, power generation, retail trade, financial services, tourism and manufacturing. 
The mining sector is the backbone of the economy and development of Guinea. With proper management of these resources, it can fund all other development sectors. Multinational mining industries are essential for the financing and operation of these minerals. This is why Guinea has established contracts since independence to develop these strategic areas for its economic takeoff. Among the mining companies, we have; the CBG( Bauxite Company of Guinea), the government owns $49 \%$ and $51 \%$ with Halco consists of a consortium of foreign companies Canadian Alcan, Alcoa and Reynolds subsidiary of the United States; Pechiney of France VAW Comalco German and Australian. In 2003, the SBK (Bauxite Company Kindia-Debele) which was built in 1970 as part of a barter agreement with the (USSR) for repayment of loans by providing a bauxite smelter in Ukraine with management by Russian aluminum (RUSAL). In the same year, RUSAL planned to buy the first smelter in Africa (Friguia) for its privatization and modernization.

Guinea has a very large amount of precious stones which attract much private investors. Gold and diamond extraction was until recently local and even informal, but since the company Ashanti Goldfields Ghana commences operations in Guinea, the country has experienced a large influx of gold mining companies like De Beers (South Africa) \& Hymex Trivalence (Canada) and Aredor Holding Company (Australia). For FDI projects during the period from 1997 to 1998 who proposed a restoration of the railway by the Slovak Railways in the amount of $\$ 200$ million, an exploration of 45 million gold by Ashanti Goldfield and \$ 24 million in diamonds from Guinea Gold Corporation (SAG) and Hymex diamond, \$ 20 million for the modernization of Iran and project operation 8 million Beers diamonds. An average from17, 55 million of FDI.When investor's forum organized in 1999 by the Guinean government with the support of development partners (OPIP and UNIDO) invited 500 prospective investors with more than 100 investment projects. During 2000 and 2001, there was an increase in investment of about \$ 63.4 million of FDI and an average of \$ 35.5 million in the country.

In 2004, the Mining Company of Dinguiraye (SMD) and SAG with two other companies in the mining sector have made significant investments. Global Alumina proposes to fund $\$ 2.5$ billion for the alumina refinery in Sangarédi even as Alcoa and Alcan negotiating in the same frame for starting an alumina refinery. In the same vein, the company of Guinea Alumina (CAG) has passed one joint venture with Global Alumina, BHP Billiton, Dubai Aluminum and Abu Dhabi's Mubadala Development which is directly followed by work: study feasibility infrastructure construction, installation refinery and transport network.

In 2008, the project Alcoa and Rio Tinto-Alcan was the largest private investment in sub-Saharan Africa. The above set-backs in the trends of Guinea's FDI inflows can be largely attributed to the political instability that plagued the country following the death of former President Gen. Lansana Conte in 2008 .The oil industry for offshore Guinea, Hyper dynamic oil Exploration Company dropped $70 \%$ of its concession due to political instability and indecision of the Guinean authorities. During the transition there is speculation of a joint venture between China Sonangol, China International Fund (CIF) and Guinean government, called the Guinean Develop Corporation (GDC) for a turnover of $\$ 7$ billion against the development infrastructure: construction of railways, roads, ports, hydroelectric, urban transport, and the creation of a national airline.

In 1992, the station was liberalized to allow private companies to invest in this sector where the acquisition of Telekom Malaysia with $60 \%$ of the company Sotelgui. In the mobile sector there is the arrival of several telecommunications operators as a challenger to the parent company: Spacetel (Israel), Telecel (United States) Areba, a branch of MTN in Africa. The company was incorporated in South Africa, the Company Intercel, Orange and Cellcom.

In the manufacturing sector, there is the presence of large foreign companies including companies operating management SARU and Vivendi of France, the company SEEG (Société de L'exploitation des Eaux de Guinée) and Grand Moulin de Guinea.

Globalization strategy for the Guinean government and the banking sector is a very important in the provision of goods and services. Among the number of foreign companies operating in this sector we have among others like: International Bank for Trade and Industry (BICIGUI) Central Bank of Guinea; Bank Moroccan developed; Society General Bank in Guinea (SGBG) and Ecobank. They actively participate in these operations supply of goods and services have any category: customer, retail, investment and transaction banking services to governments, financial institutions, multinationals, international organizations, small, medium and micro enterprises and in particular. In the above mentioned sectors, investor's in general particularly Chinese investors should focus on prospects for technical schools, and insurance services for major projects. Already Guinea with these advantages as a supplier of natural resources and related services. The character of what is needed for the training of technicians is the constant mention of a local unskilled labor and availability of young Guineans to acquire additional training. However, most businessmen lack the qualification and knowledge about entrepreneurship.

This scope of TNCs activities in mineral sector has obviously increased China's interest in Guinea's mining sector significantly. Within a short duration china has participated heavily in the development of Guinea's oil industry including the construction of transportation infrastructure. The growing involvement can also open opportunities for intensified Chinese. 


\section{Attracting Sino FDI to Guinea}

By following these principles china supports and participates in the South-South cooperation. This cooperation with developing countries is already part of its strategy of opening to the outside any azimuth, and also to increase its investments in Africa, particularly Guinea which could bring profits to both countries. This cooperation has continued to enrich its size as it becomes larger. China is a major producer of steel, seeking to diversify its sources of raw material and in the other hand Guinea with important natural resource of soil and subsoil. This demonstrates the potential role of the transnational corporations in the establishment and development of partnership between the private sector in both countries. This would likely promote small and medium enterprises; increase trade and foreign investment flows has become nowadays the best strategies for business growth. It is important to remember that during the 1980s, Guinea has brought major changes in economic policies giving more weight to the private sector and economic liberalism. Since that time, Guinea is engaged in a process of transition from a system of control of public enterprises and enterprises by the government into a market economy system.

During the 1987 - 1991 program of recovery was initiated: Structural Adjustment Program (SAPs) called for \$ 670 million spending until 1989, with $42 \%$ for local development. This policy was intended to reduce the administrative complexity, its heavy dependence on mining and diversified economic activities, while at the same time ensuring improvement in the macroeconomic performance for sustained growth and development. Improvements in such policies has been very instrumental in attracting FDI inflows into the country which has in turn enhanced macroeconomic performance and helped in steering the economy to the attainment of the least growth pace needed to attain the Millennium Development Goals set by the United Nations.

\subsection{China's Policy on Outward FDI}

The history of FDI flows from China can be described as short but extremely stunning. Virtually non-existent during the economic reforms that took root in the late 1970s, Sino FDI remained insignificant through the end of the last millennium (Refer to Table 1). However, at year-end 2008, the annual volume of China's cross border investments had grown to around USD 170 billion (Chinese Ministry of Commerce- MOFCOM, 2009).

Table 1. Regulations on China's outward FDI

\begin{tabular}{|c|c|c|}
\hline Area & Regulation & Time of promulgation \\
\hline Approval & $\begin{array}{c}\text { Provisions on the Examination and Approval of } \\
\text { Investment to Run Enterprise Abroad (MOFCOM). The } \\
\text { Interim Measures for the Administration of Examination } \\
\text { and Approval of the Overseas Investment Projects } \\
\text { (NDRCI). } \\
\text { Details Rules for the Examination and Approval of } \\
\text { Investments to Open and Operate Enterprises Abroad } \\
\text { (MOFCOM }\end{array}$ & $\begin{array}{l}1 \text { October } 2004 \\
1 \text { October } 2004 \\
1 \text { October } 2004\end{array}$ \\
\hline Encouragement & $\begin{array}{l}\text { Circular on the Issues related to Grating Financing } \\
\text { Support to Key Overseas Projects Encouraged by the } \\
\text { State (NDRC). Circular on the Supportive Credit Policy } \\
\text { on Key Overseas Investment Projects Encouraged by the } \\
\text { State (NDRC and Export-Import Bank of China). }\end{array}$ & $\begin{array}{c}9 \text { May } 2003 \\
27 \text { October } 2004 \\
25 \text { September } 2005\end{array}$ \\
\hline $\begin{array}{l}\text { State-owned } \\
\text { asset } \\
\text { management }\end{array}$ & $\begin{array}{l}\text { The Interim Measures for the Administration of Overseas } \\
\text { State-owned Assets (Ministry of Finance, SAFE, etc.). }\end{array}$ & 27 September 1999 \\
\hline $\begin{array}{c}\text { Foreign } \\
\text { currency } \\
\text { management }\end{array}$ & $\begin{array}{c}\text { Circular of the State Administration of Foreign Exchange } \\
\text { on Issues Concerning Deepening the Reform of Foreign } \\
\text { Exchange Administration on Foreign Investment } \\
\text { (SAFE). Circular of the State Administration on Foreign } \\
\text { Exchange on Adjusting Some Foreign Exchange } \\
\text { Management Policies about Overseas Investment } \\
\text { (SAFE). }\end{array}$ & $\begin{array}{l}15 \text { October } 2003 \\
19 \text { May } 2005 \\
6 \text { June } 2006\end{array}$ \\
\hline Statistics & $\begin{array}{c}\text { Interim Measures for Joint Annual Inspection of } \\
\text { Overseas Investment (MOFTEC and SAFE) Statistic } \\
\text { System of Overseas Investment (MOFTEC and National } \\
\text { Bureau of Statistics). System of Advance Reporting of } \\
\text { Overseas M\&As(MOFCOM) }\end{array}$ & $\begin{array}{c}31 \text { October } 2002 \\
4 \text { December } 2002 \\
31 \text { March } 2005\end{array}$ \\
\hline
\end{tabular}


China abandoned since the 1980s, the fashion cooperation dominated or monopolized by the audience. She advanced towards the market economy as the cornerstone and starting point of the policy on FDI outflows from China. Moving towards its economic and trade relations or equality and mutual benefit, seeking efficiency and a more harmonized and transparent. Its mutually beneficial cooperation and win-win economic system favored more flexible, encouraged Chinese investors to invest abroad (Refer to Table 2). With this preferential policy, the establishment and development of partnership between the private sector and other Chinese countries experiencing rapid growth. This has played a facilitating role in providing production equipment, raw materials and processed products and technological know-how, in order to maximize their stock exchange. Their mode of investment is often two kinds generally in the form of Greenfield investments and Cross-border merger and acquisition (M\&A) of an existing local firm.

Table 2. China: authority-sharing in the approval of overseas FDI projects between central and provincial governments

\begin{tabular}{ccc}
\hline Category of project & Central government & Provincial government \\
\hline $\begin{array}{c}\text { Resource exploration project } \\
\text { Non- resource project }\end{array}$ & $\begin{array}{c}\text { Investment }>\$ 0 \text { million Investment } \\
\text { (in foreign exchange) }>\$ 0 \text { million }\end{array}$ & $\begin{array}{c}\text { Investment }<\$ 0 \text { million } \\
\text { Investment }(\text { in foreign exchange) } \\
<\$ 0 \text { million }\end{array}$ \\
\hline
\end{tabular}

Source: MOFCOM

Note: Investment refers to that from the Chinese investor

During 1990s, Chinese policy started its outward FDI and announced the "Going Global" in Chinese is (Zǒuchūqū Zhànlüè). With incentives advantages to access bank loans, simplified border procedures, and preferential policies for taxation, imports and exports. According to the Chinese foreign reserves amounting to $\$ 1$ trillion; China is set to become a major foreign investor in the developing world (UNCTAD, 2005).

Increasing foreign investment as suggested by transactions such as the acquisition of IBM's Personal Computer business by Lenovo in 2004 and others. This can play an important role in improving foreign investment policy framework regulations in the internationalization of Chinese companies in the world. Chinese FDI stock reached USD 246 billion in 2009, well over eight times the USD 28 billion recorded in 2000 and far above the negligible USD 4 billion of 1990, making the nation the largest outward FDI investor among developing countries. During the global financial crisis of 2008 - 2009, unlike most countries, Chinese FDI outflows increased. These phenomenons has brought a major role in facilitating the transfer of production capacity in China to other countries, deepening mutual international cooperation on natural resources and ensure an effective response to the crisis and even increasing right Beijing to discuss the improvement of the international economic order. At present, the Chinese government has done much to promote outward FDI by building mechanisms to guarantee its effectiveness.

As of mid-2009, China had established bilateral economic and trade agreements with over 100 countries and regions all over the world and signed at least 127 Bilateral Investment Treaties (BITs), making China number two in the world for BITs (Duanyong, 2011). An important development in the strategy of "Go Global" was the foundation of the China Investment Corporation (CIC), China's sovereign fund in 2007. Placed as one of the most important on the world, CIC has made several purchases, primarily in the raw materials sector. For China, the long term strategic significance is that the rapid development of outward FDI can contribute to deepening domestic reform and the opening-up process, and lead to greater Chinese participation in fostering a more equitable form of economic globalization. Outward FDI makes it possible for China to attain and safeguard its development interests in both resource-rich and resource- poor regions of the world, particularly Africa.

\subsection{Chinese FDI Outflows}

As mentioned above, it is important to remember that since the 1980s, China has embarked on a historic process of transition from a state economy to a market economy. The Chinese economy has grown rapidly with an amount of FDI estimated $\$ 100$ million in 1980 to $\$ 12$ billion in 2005 with a large amount of reserve dollars in the world "China dollars". The economic expansion of outward FDI, production for industry and agriculture are among the first class in the world. With the government's strategy "Going Global" policy, it seems to be in the future one of the largest sources of FDI.

Since the economic reforms and an opening China to the outside. China has started recording FDI outflows but with a low amplitude. It was in 1990 that China had increased its speed with a large investment and the number of projects in the world. At the end of 2000 the Chinese began 6.296 FDI projects in 140 countries and regions. In terms of the value of its total investment, $25 \%$ in Asia, 37\% in North America, Oceania and Africa 17\%. Until the end of 2005 the amount of Chinese investment in Africa totaled USD 6.27 billion with the installation of more than 800 companies in various 
sectors distributed in 49 countries. Despite all these years, it was in 2008; Chinese FDI stock in Africa has reached a significant level (See Figure 2).

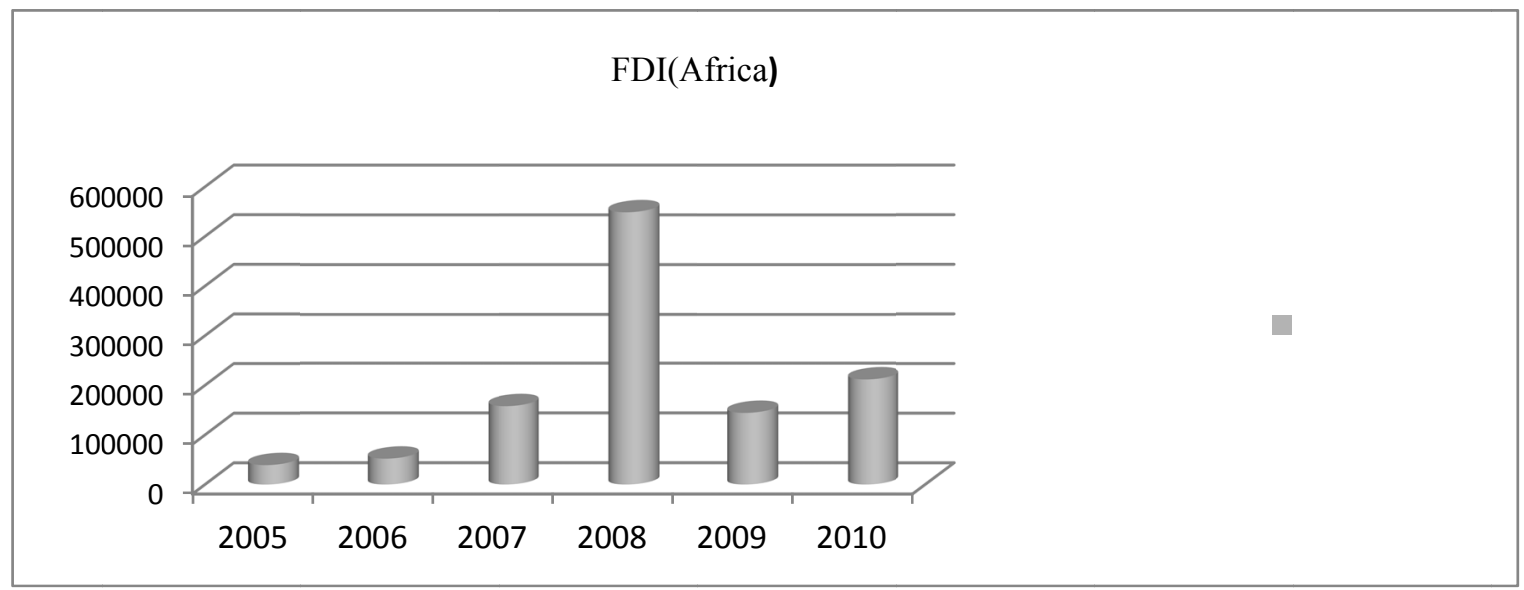

Figure 2. China's FDI outflows to Africa to 2005-2010

Source: World Bank and Yearbook

The stock of FDI in Guinea was estimated at $\$ 686$ million at the end of 2005 (Note 1). An UNCTAD report (2007) indicates that the stock of Sino FDI in Guinea was estimated at $\$ 44.2$ million (Note 2), or 6.4\% of FDI stock in Guinea. In November 2005, during the visit of Chinese First Prime Minister in Conakry, Guinea and China agreed and signed a renewable investment agreement for a period of ten years. Although the investment code of Guinea is very enticing, foreign countries are often motivated to negotiate investment agreements to include provisions not found in the code. The provisions of the most favored nation, the transfer of investments and benefits, limits to expropriation, dispute settlement, and the original rule that always lead to disputes are no longer covered by the internal taw of Guinea.

Despite the fact that Chinese FDI flows have been rising since 2004, Guinea has lagged behind its West African counterparts in terms of stocks and Sino investments abroad. Despite this, Guinea has recorded a stock of USD 1443.93 in 2007, during the same period Nigeria and Ghana recorded three times and four times less, respectively. The same trend was also observed for inputs Chinese foreign investments in the region.

China has tagged on the list of foreign investors in Guinea in 2012, with France and the US on top for the last ten years. However, a comparative analysis with Guinea shows that some African counterparts still need to ratchet up attempts to attract foreign investment from China. In fact, the horizon would have been much worse if Angola, Ethiopia and Sudan had been included in the analysis since the quest of the two countries for these investments in the areas of Sino infrastructure in recent years can be described as insatiable (See Figure 3).

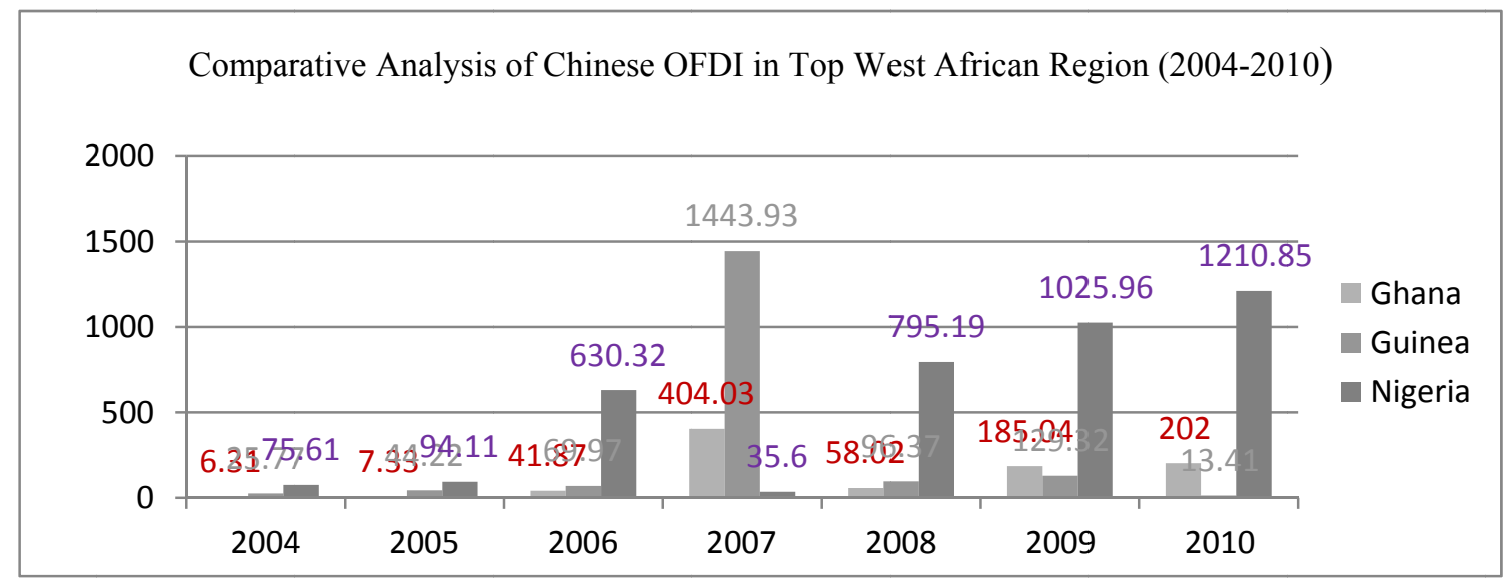

Figure 3. Sino OFDI stocks by country in WAC Region 2004-2010 (Millions of USD)

Source: MOFCOM Data, Author Analysis 
Whereas the sectorial distribution of the stock of Chinese FDI in Guinea was not readily at hand at the time of compiling this study, extraction, manufacturing, transport and communication remained the areas attracting most FDI (Refer toTable 3). For instance, in 2002, Chinese company Yahé Shandong Guinea textile Complex bought the entire share capital of the former public textile factory Sanoyah. The company currently has 22 Chinese experts, 97 Guinean workers and 25 guards with its main production being hundreds of models and drawings of different colors on super wax printed cotton. Another textile manufacturing project is the Huali Society of Handcrafted Industry Products of Guinea (Produits Artisanaux Huali de Guinée) established in 2004, with funding of clean textiles industry in Shandong Province of China. Its production includes lace fabrics, lace curtains, lace linens, table cloths, and other household items.

Table 3. The sectoral distribution of major Chinese companies currently a commercial presence in Guinea

\begin{tabular}{|c|c|c|}
\hline 1 & Agriculture, hunting, forestry and fishing & The Soguicoda (ISIC11),Forêt forte(ISIC12) \\
\hline 2 & Mining & China Sonangol \\
\hline 3 & Manufacturing & $\begin{array}{c}\text { Company Yahé Shandong Guinea textile Complex } \\
\text { (Guinée Complexe Textile Yahé Shandong (ISIC } \\
\text { 32);Society of Industry; Produits Artisanaux Huali de } \\
\text { Guinée (ISIC 32) }\end{array}$ \\
\hline 4 & Electricity, gas and water & China International Water \& Electric Corp \\
\hline 5 & Construction and public works & $\begin{array}{l}\text { China Henan Company (ISIC 50); CGC(ISIC 50) } \\
\text { Huanxi Sichuan (ISIC 50); The Jinya Jiangsu of China } \\
\text { (ISIC 50) }\end{array}$ \\
\hline 6 & Transport, warehouse and Communication & Huawei Technologies(ISIC 72) \\
\hline 7 & $\begin{array}{l}\text { Banks, insurance, real estate and services } \\
\text { provided to businesses }\end{array}$ & Chinese International Fund(CIF); Eximbank-China \\
\hline 8 & $\begin{array}{c}\text { Services to the community, social and personal } \\
\text { services }\end{array}$ & La Pharmagui-Orient en Guinée (ISIC 92) \\
\hline 9 & $\begin{array}{l}\text { Wholesale and retail trade and restaurants and } \\
\text { Hotel }\end{array}$ & $\begin{array}{l}\text { Company for International Trade; Economic and } \\
\text { technical XIAN (ISIC61); Chinese center for } \\
\text { investment; Operation and commercial (CCIEC) } \\
\text { (ISIC61); Grand Hotel in Conakry (ISIC63); Company } \\
\text { International Economic and Technical Cooperation of } \\
\text { Hunan Province (CHITEC). }\end{array}$ \\
\hline
\end{tabular}

Source: Guinean Embassy in Beijing (2012)

Chinese company Huawei Technologies is present in the telecommunications market in Guinea as a provider of customized network solutions, optical networks, fixed networks, mobile networks and networks intelligent. The company works together with the incumbent telecommunications operator of Guinea, Sotelgui, in improving network capacity and service. It currently provides Sotelgui with terminals for fixed telephony and wireless Internet Private. Others include; Pharmagui-Orient Guinea, a Sino-Guinean mixed capital per Share Company, which opened its doors in October 2001 as a whole sale supplier of drugs and the 2009 .The Government through the Ministry of Mines announced to have negotiated an agreement with CIF about $\$ 7$ billion over five years. The Protocol provides for a joint venture between the CIF, China Sonangol and Guinean Government to form a new oil company; Guinean Development Corporation (GDC) with $15 \%$ owned by government with the opportunity to continue its expansion.

\subsection{Opportunities for Chinese FDI in Guinea}

The influence of investment is crucially dependent on the size of the domestic market and regional market. However, there are a number of market sector including the growing demand for goods and services that is not sufficiently satisfied, either because of high prices of goods or poor quality. And also a number of industries in terms of agriculture and agro-processing industries; mining and reserves in hydropower. In addition, the oil, gas and other natural resources has sufficient reserves too. All this represents profitable investment opportunities and is an important source of attracting foreign investment, as we detailed below. 


\subsubsection{Agriculture and Agro-industries}

Given the potential available to Guinea in the agricultural sector, with about seven million hectares of arable land and an annual rainfall of about 400 billion $\mathrm{m} 3$ of water, only $2.6 \%$ percent is used productively(UNCTAD, 2001).Guinea is naturally endowed with huge agro-pastoral resources rich in organic matter and very fertile soil, and can handle all types of agriculture according to these four natural regions and to the different cultures: crop growing, industrial and exports, including livestock and fisheries that can help to develop a variety of agricultural products. To encourage investment in this sector, Guinea must increase its efforts to open up these productions areas to major centers of consumption, in other hand improve communication sector; road transportation, ports and airport, so that agricultural products are efficiently exported abroad.

Based on the indicators, there is vast potential for Chinese firms in Guinea for investment in the areas of agriculture and agro-industries. The Chinese enterprises in this sector could serve as cross transmission for technology transfer to SMEs, and the same time the transfer of their knowledge of global markets. By this way, Chinese FDI could contribute in defeating the barriers to SME development: the shortage of credit, know-how and information. Attracting Chinese investors, recommends the use of commercial relations and encouraging the importing companies to reinvest their value-added activities of the Guinean economic.

\subsubsection{Mining}

The Guinea economy is driven by the mining sector for it accounts for over a quarter of its gross domestic product and more than $80 \%$ of its foreign exchange earnings; it is the largest global supplier of bauxite and booming iron ore exporter - have signed contracts worth billions of bauxite, iron, gold and diamond for mining companies to control the ownership and financing of projects, including the development of giant Simandou reputed to be the largest untapped iron ore deposit in the world (See Figure 4).

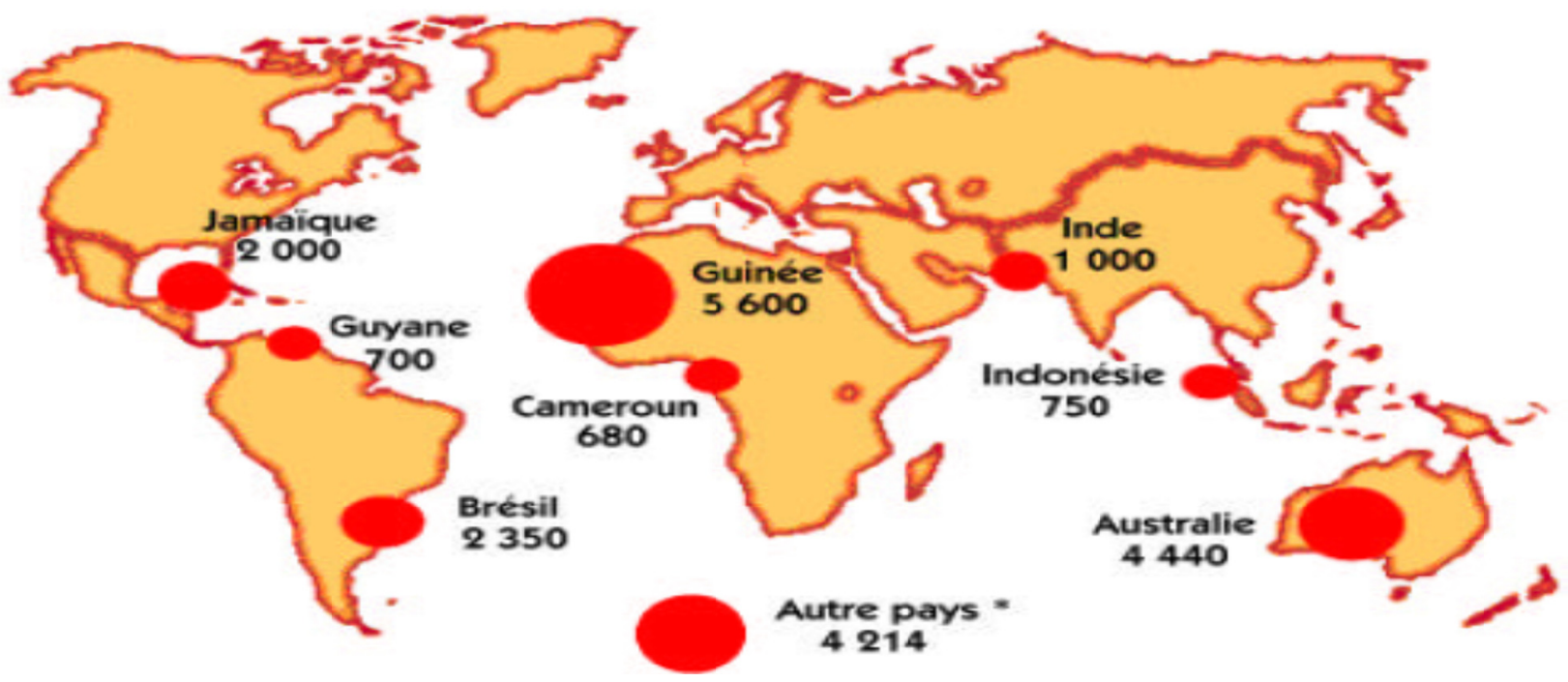

Figure 4. World's bauxite reserves (million tons)

Source: United Nations Industrial Development

To restart the Guinean mining policy, the new government has created a body that denominates the Centre for Mining Promotion and Development (PCRD) supported by the World Bank and the International Monetary Fund. This is to harmonize the Guinean mining code with the creation of a national database of geological information. The new mining law that aims to reduce the share of the state and the promotion of foreign investment, will be a "one stop window for investors", in order to ensure partners and tax incentives for new investors.

Guinea has one of the highest bauxite reserves in the world's largest and one of the largest producers, after Australia. Estimates of Guinea contain almost $24 \%$ of global bauxite reserves, $94 \%$ of African production and accounts for $20 \%$ of GDP and $90 \%$ of these exports. Indeed, Guinea has significant iron deposits including gold and diamonds which is almost unexplored and future potential for other metals unidentified could be a great attraction for foreign investors to develop its basement, proposing projects characterized by a program to modernize production process and restructure the aluminum industry to make it more successful and beneficial for the national economy. 
Some mining investment depends on improved infrastructure, specially Rio Tinto deposits feasibility studies of infrastructure Simandou, according to the Transaction Agreement, the activities construction, maintenance and operation of rail and port infrastructure project will be assigned to SPV Simfer (51\%Guinean Government and 49\% of shareholders Simfer).To that effect, in the mountains of Nimba and Simandou an important iron ore were discovered along the border between Liberia. In 1974, the Mifergui-Simandou and Mifergui-Nimba mining companies were formed to exploit these deposits with the Government holding half interest in the companies according to Guinean government transaction agreement, a joint venture led by Rio Tinto (Simandou), IFC; AIOG, and Simfer Please AIOG, BTG Pactual and BHP Billiton (Nimba) has obtained a permit to use the Guinea's transnational system.

\subsubsection{Energy and Power}

Guinea has the largest reserves of hydropower (6.600MW) across Western Africa. Largely unexploited before, their realization was recently improved with the construction of the Garafiri dam that was completed in 2000 with financing from the international community complemented by an unprecedented public participation. Built on the Konkouré, the dam holds back 1.3 billion $\mathrm{m} 3$ of water liberating power of $50 \mathrm{MW}$. By adding the installed thermal power of $85 \mathrm{MW}$, the annual electricity production reached $760 \mathrm{GW} / \mathrm{h}$ in 2001 with $90 \%$ of this consumed in the Conakry- Kindia governorate. The possibilities of hydroelectric development are impressive in Guinea. On- going projects include the hydroelectric complex Souapiti-Kaleta $(600 \mathrm{MW}+150 \mathrm{MW})$ to power the aluminum plant at Fria and the Sangaredi Fomi (75 and $150 \mathrm{MW}$ ) for supplying the Upper Guinean and Forest Guinea.

Guinea's energy sector depends on the field of thermal and hydraulic energy to produce power. In 2002, energy production climbed to 0.284 million $\mathrm{kW}$, with $49 \%$ hydroelectric and the rest thermal fuels. For a total of 0.773 billion $\mathrm{kw} / \mathrm{h}$, hydropower provided 0.443 billion $\mathrm{kw} / \mathrm{h}$ and renewable fuels 0.340 billion $\mathrm{kw} / \mathrm{h}$ with a total electricity consumption of 0.719 billion $\mathrm{kw} / \mathrm{h}$.

According to the West African Power Pool (WAPP) accord in October 2000, which Guinea is a signatory to the agreement to start a project to improve the hydropower deliver in the West African nations. That policy decision; is for increasing energy power services and intersect their electricity frameworks; which can also promote the development of renewable energies: the presence of a liberalized electricity sector, possession of hydropower potential and significant solar energy pilot projects for small hydroelectric power plants, in accordance to the agreement, which is to harmonize legal and regulatory framework governing the electricity sector in each member country( Renewable Energy Policy for ECOWAS).

\subsubsection{Others (Oil and Gas)}

Apart from Guinea's mining and agricultural potential, the field of oil and gas is not left behind. Until recently, Guinea had not identified its reserves of oil or natural gas. It was only in 2003, that the Guinean government has begun to explore the liberalization of rules that resists attracting foreign investors in this sector. According to 2002 statistics, the average consumption and imports of refined petroleum in Guinea was 8,730 barrels per day but no exact number for natural gas or coal. The Petroleum Code of $23^{\text {rd, }}$ September 1986 is being revised by a commission composed of three departments: Commerce, Mines and the environment with the office of the President and developments partners. It is expected that the committee will finalize a code more attractive while linking mining contracts with concessions for infrastructure development, an arrangement somewhat similar to the way "Angola" infrastructure financing. Today, only one company in the United States Hyper dynamic is operative in Guinea. Since 2010, the company completed seismic surveys and announced its intention to commence drilling for oil in 2011. However, the future of the concession is not clear, with HE President Alpha Condé has promised to revise the contracts signed from 2006 until today. Since the elimination in 1995 of the public monopoly on the importation of petroleum products and marketing that has allowed private distributors to operate in Guinea. At present, the French oil company Total and Shell-Guinea- is now an independent company, which is in talks to merge with potential foreign partners and local business COPEG (Oil Company of Guinea) are companies dominant position in the oil sector.

\section{Data and Methodology}

\subsection{Data and Variables}

Data and variables an analytical ex-post factor is used. Data collected for this study was based on resultant sources of data and comparative analysis from different sources: secondary data and information (reports, journals and internet websites). In addition to the officially approved data, we consider another data set that is only available for a short sample period between 2004 and 2010, was found in papers of international organizations involved in the field of The Statistical Bulletin of China's Outward Foreign Direct Investment (2010). It is important to note that the correlation between FDI and growth is reciprocal. Hence the reason that FDI may well improve the efficiency of income in the 
household and at the same time the level of economic growth in the recipient country. The dependent variable is measured by the rate of Chinese FDI inflows towards Guinea. Theoretical and empirical evidence in this study considers mechanisms that play important roles in attracting FDI; market size, economic growth, employment as a percentage of total population aged 15-24, degree of trade openness that is calculated by dividing the GDP by the sum of exports and imports; and trade policy for the analyzes of different combinations.

\subsection{Econometric Model}

Regression Equation

$$
F D I_{=\lambda+\alpha 1} T V+{ }_{\alpha 2} G D P_{G+\alpha 3} G D P_{C}+{ }_{\alpha 4} E M P L O Y M E N T+{ }_{\alpha 5} O P E N N E S S+\varepsilon
$$

\subsection{Discussion of Results}

The result of the analysis in this model is summarized in the tables (see appendix). It is clear in Table 4 that the $\mathrm{R}$-squared is positive or almost zero value in our linear regression analysis, but all the coefficients are still not significant. Contrary to most resource-rich countries, we can conclude that in Guinea the level of Chinese FDI is not the driving force of bilateral economic cooperation. As shows the below table.

Table 4. Chinese foreign direct investment in Guinea

\begin{tabular}{cccccc}
\hline Parameters & R Square & $\begin{array}{c}\bar{R} \text { Adjusted } \\
\text { Square }\end{array}$ & $\begin{array}{c}\text { Std. Error of the } \\
\text { Estimate }\end{array}$ & Sig F change & Remarks \\
\hline Y (X, Z; W, V, T) & 0.681 & -0.117 & $8.99368 \mathrm{E} 6$ & 0.618 & Significant \\
Y (X, Z; W, T) & 0.681 & 0.255 & $7.34331 \mathrm{E} 6$ & 0.365 & Significant \\
Y (Z, W, V, T) & 0.678 & 0.248 & $7.37782 \mathrm{E} 6$ & 0.369 & Significant \\
Y (X, W,V,T) & 0.639 & 0.158 & $7.80678 \mathrm{E} 6$ & 0.425 & Significant \\
Y (X, Z; W) & 0.572 & 0.251 & $7.37782 \mathrm{E} 6$ & 0.290 & Significant \\
Y (Z, W, V) & 0.607 & 0.313 & $7.05391 \mathrm{E} 6$ & 0.248 & Significant \\
Y (X, W,T) & 0.629 & 0.351 & $6.85278 \mathrm{E} 6$ & 0.223 & Significant \\
Y (X, Z; T) & 0.534 & 0.184 & $7.68621 \mathrm{E} 6$ & 0.337 & Significant \\
Y (Z, W) & 0.471 & 0.259 & $7.32254 \mathrm{E} 6$ & 0.204 & No Significant \\
Y (W,T) & 0.484 & 0.277 & $7.23433 \mathrm{E} 6$ & 0.192 & No Significant \\
Y ( Z ) & 0.003 & -0.164 & $9.17852 \mathrm{E} 6$ & 0.905 & No Significant \\
Y (X) & 0.066 & -0.090 & $8.88321 \mathrm{E} 6$ & 0.540 & No Significant \\
Y (T) & 0.004 & -0.162 & $9.17011 \mathrm{E} 6$ & 0.876 & No Significant \\
Y (W) & 0.398 & 0.298 & $7.12969 \mathrm{E} 6$ & 0.093 & \\
\hline
\end{tabular}

Source: Regression Analysis based on authors' calculations

$\mathrm{Y}(\mathrm{X}, \mathrm{Z} ; \mathrm{W}, \mathrm{V}, \mathrm{T})$ (Note 3 ) significant. It means $68 \%$ of the variability in FDI is justified with combination by four independent variables. In the same way; low $\bar{R}$ adjusted square explains that unimportant variables occur in the regression equation.

$\mathrm{Y}(\mathrm{X}, \mathrm{Z} ; \mathrm{W}, \mathrm{T})$ significant. It means $68 \%$ of the variability in FDI is justified with combination of the four independent variables. In the same way; low $\bar{R}$ adjusted square explains that expected $\mathrm{V}$ other unimportant variables occur in the regression equation.

$\mathrm{Y}(\mathrm{Z}, \mathrm{W}, \mathrm{V}, \mathrm{T})$ significant. It means $68 \%$ of the variability in FDI is justified with combination of the four independent variables. In the same way; low $\bar{R}$ adjusted square explains that like $\mathrm{V}, \mathrm{X}$ is also unimportant variable in the regression equation.

$\mathrm{Y}(\mathrm{X}, \mathrm{W}, \mathrm{V}, \mathrm{T})$ significant. It means $64 \%$ of the variability in FDI is justified with combination of the four independent variables. In the same way; low $\bar{R}$ adjusted square explains that $\mathrm{Z}$ is also unimportant variables in the regression equation.

$\mathrm{Y}(\mathrm{Z}, \mathrm{W}, \mathrm{V})$ significant. It means $61 \%$ of the variability in FDI is justified with combination of the three independent variables. In the same way; low $\bar{R}$ adjusted square explains that excepted $\mathrm{X}$ and $\mathrm{T}$, there are another unimportant variables in the regression equation.

$\mathrm{Y}(\mathrm{X}, \mathrm{W}, \mathrm{T})$ significant. It means $63 \%$ of the variability in FDI is justified with combination of the three independent variables. In the same way; low $\bar{R}$ adjusted square explains that excepted $\mathrm{Z}$ and $\mathrm{V}$, there are another unimportant variable in the regression equation. 
$\mathrm{Y}(\mathrm{X}, \mathrm{Z}$; V) significant. It means $57 \%$ of the variability in FDI is justified with combination of the three independent variables .In the same way; low $\bar{R}$ adjusted square explains expected $\mathrm{W}$ and $\mathrm{T}$, there are other unimportant variables in the regression equation.

$\mathrm{Y}(\mathrm{X}, \mathrm{Z} ; \mathrm{T})$ significant. It means also $53 \%$ of the variability in FDI is justified with combination of the three independent variables. In the same way; low $\bar{R}$ adjusted square explains expected $\mathrm{W}$ and $\mathrm{V}$, there are also other unimportant variables in the regression equation.

In general, we show that when the dependence variable FDI is in combination of at least trios independent variables, the coefficient of determination R square varies between $53 \%$ and $68 \%$. We conclude that there is an evidence linear regression relationship here. There are weak linear relationship between FDI and GDP China, between FDI and Employment, and between FDI and Trade Volume (TV). But there are almost evidence linear regression FDI with two variables. GDP and TV are not to minimize, but do not show significant relations with FDI. May be the FDI effect towards GDP; as a trade could be an informal one, which does not make much impact on GDP. But the cheaper goods from china improve the living conditions of populations. However, the unfair competition caused by this fact affect the activities of local businesses. The results of this study show that disparities among countries in attracting investments range from their geographical locations, conditions of infrastructure, corruption levels, and income yields to implementation of the policies by the governments. It recommends policies at both national and bilateral levels in order to increase large Chinese FDI inflows towards Guinea and improve the forecast for macroeconomic and its constant development.

\section{Conclusion and Recommendations}

This study examines the determinants and policies for attracting Chinese FDI to Africa by particularly analyzing major characteristics for Guinean economic development. Due to lack of pertinent information, we have attempted to analyze this investment using indirect methods. Given the fact that Chinese investments in Africa are essentially tied, we interpreted the fast growing imports and the turnover of economic cooperation with China as relevant signals of this engagement. By doing so, we cannot disentangle the effect of investment flows (in the sense of DAC definitions) from the effect of true aid flows or other financial flows, but in any case no data source provides accurate data on investment flows compatible with the DAC (Development Assistance Committee) definition.

Whereas it has been widely accepted that Chinese OFDI; may contribute greatly in the socio-economic development of many African countries, the idea that emerges from the literature in this study is that Guinean has not recorded much advantage in increasing large Chinese FDI. The results of this analysis confirm the R- squared is good which means that our regression is valid, but all the coefficients are still not significant, thus we can conclude that in Guinea the level of Chinese FDI is not that promising.

As reflected in this study, Guinea's dismal performance has been largely attributed to the combined effects of high costs of doing business due to Guinea's landlockedness, macroeconomic instability, weak infrastructure, lack of policy transparency and red-tape tendencies by government agencies, corruption and weak governance structures, language and cultural differences, intensification of rivalry for FDI flows justified by economic globalization, and poor strategy, among others. Reversing this trend need harmonized policies at both national and bilateral levels. As well; it can be benefit to the country's policymakers to take a wise decision to encourage investors in order to facilitate more fruitful investment decisions.

However, there is room for improvement for Guinea as there is a glimmer of hope because of the current developments trends in recent years. The prospects look bright with foreign investors beginning to exploit Guinea's unique location at the heart of SSA, a strong natural resource base, a fully liberalized economy, a young and trainable labourforce, increased security of investments and the various investment incentives currently being provided by the government. Chinese investments offer a new opportunity for Guinea to reshape its FDI promotion strategies in the best manner that may improve its constant development. A careful monitoring and appropriate mechanisms need to be put in place to ensure compliance by all parties. With government improving the country's economic development, they have improved political climate, principle of work and recovery system taxes. In this way, the resources that have often been considered untapped can truly act as the source for the socio-economic development of Guinea. That's why; one may argue that not all the literature reviewed in this article respond to the research questions; but it will hopefully make the reader understand why some countries have been and continue to be more appealing than other to attract Chinese OFDI.

In the business-cooperation which is favored by forums, such as Forum China-Africa Cooperation (FOCAC), present many opportunities for African countries to enhance Chinese FDI. By way of this progress, new business 
partnerships can be mentioned and business climates amplified to a common benefit. As such, it is one of the main motivations of this study that African policymakers recognize the opportunities presented by the Chinese commitment to invest in these countries and promote its constant development, the same with Chinese experience.

Finally the main objective of this report is to help Guinea in attracting and increasing more FDI inflows, specifically Chinese FDI inflows. Particularly, the study will review the policies taken by governments of China and Guinea to attract FDI by analyzing the root of China's success and comparing the policies of Chinese government to those of Guinean government. Based on the assessment and summary of this study, the following propositions can be put forward for both Guinea and Chinese policy makers to consider: Some of the policies suggested by this study include:

1- The government of Guinea should prioritize infrastructural improvement to give fresh impetus to encourage more cooperation in road and rail network projects in areas such as buildings, communications, transportation, roads and power supply. Strategic partnership with the Chinese government in projects based on the "Angola Mode" would go a long way in achieving this goal. This will greatly improve accessibility, reduce expenditure on these facilities, thus lower transportations costs, promoting employment, and growing the magnetism of the country to overseas investors.

2- Guinea policy makers should fast track efforts aimed at enhancing regional integration, such as the tri-party plus scheme (ACP, NEPAD, ECOWAS, WAMZ, MRV and GRDO) and restoring stability in macroeconomic variables in order to promote currency stability and a financially secured system. By putting in place prudent macro-economic policies that restore stability in the economy to ensure that fluctuations in interest rates are nominal and real, to serve as measures to encourage investors regain confidence in the markets and thus boost the attraction of foreign direct investment inflows into the country.

3- Diversification of Guinea's economy through Sino-Guinean joint ventures in agro processing, mining extraction and manufacturing should be one of the priorities for the Sino-Guinean investor relationship going forward since Guinea relies on the export of raw materials like the bauxite, gold and alumina to China for exchange currencies which exhibits its economy to notably large terms of trade shocks. Diversification of its economy beyond the primary sector can make possible to mitigate influence or impact of these shocks and promote an avenue for attracting efficiency-seeking FDI in the secondary and tertiary sectors in the country's development.

4- Chinese policymakers should consider extending more technical assistance to Guinea in order to make better investment climate in the country and enhance its ability to receive many foreign investors as well as equipping them with good technical base to increase in areas such as: training of citizens, health investment, infrastructure construction, telecommunications and industrialization etc. Indeed, Guinea's structural disadvantages could be partially reduced if Chinese official development assistance (ODA) should be more operative in conjunction with the FDI. Recent studies have shown that ODA can be able to act as a trigger for the stimulation of the limited impact of FDI in Least Developed Countries (LDCs) like Guinea.

5- Expand and capitalize on the existing regulatory framework for renewable energy development. Guinea has the significant advantage of a comprehensive regulatory framework for renewable energy promotion. Guinea should capitalize on this advantage by meticulously implementing existing stipulations and communicating the investment incentives to potential renewable energy investors. In addition, Guinea should build on the existing framework and consider additional incentives, for example targeted capital subsidies or tax exemptions.

6- Reconsider political priorities in light of potential Chinese involvement in solar power expansion. Creating demand for solar power equipment (PV as well as thermal) is one of the drivers behind China's engagement in Africa's renewable energy sector. Given the potential for solar power in Guinea and the opportunities for increased Chinese investment in this sector, the government could consider adjusting the current priorities of its Renewable Energy Policy and putting greater emphasis on solar power development.

7- Explore possibilities for China's continuous involvement in large hydropower development. Whereas Guinea cannot build on longstanding Chinese involvement in the country's infrastructure sector, the evolving Chinese engagement in Guinea's oil sector opens opportunities for larger package deals that include hydropower development. China's interest in financing planned hydro projects in Guinea also points to this possibility. Guinea should explore these opportunities in light of its domestic needs as well as with regard to social and environmental costs. A careful case-by-case assessment of the opportunities and downsides of larger infrastructure deals and resource-backed financing will be necessary. 
8- Adopt liberal trade rules to boost imports of renewable energy equipment, not only but especially from China. As long as no domestic manufacturing capability for renewable energy equipment exists, Guinea can follow non-discriminatory trade policy towards other importers under World Trade Organization (WTO) regulation.

9- Strengthen domestic regulation on environmental and social standards for project implementation. The guidelines on social and environmental scheme put forward by the China Ex-Im Bank provide Guinea with a starting point for managing undesired impacts of large hydropower projects. The guidelines stress the primacy of the host country's domestic legislation with regard to project implementation. Guinea should therefore revise its domestic stipulations on infrastructure guidelines to include adequate assessment of indirect costs as well as proper procedures of monitoring, reporting and public consultation. Existing international stipulations like the World Commission on Dams (WCD) guidelines can serve as a blueprint for these efforts. At the same time, Guinea should increase domestic capacity to conduct comprehensive impact assessments for large hydro projects and expand domestic monitoring and verification capacities to enforce legal requirements.

10- Actively cooperate with China's financial institution (especially China Ex-Im Bank) on the enforcement of standards vis-à-vis Chinese construction companies. The Guinea government should cooperate closely with China's loan-providing institutions in order to enforce adherence by Chinese companies. Given the growing attention China's political actors pay towards negative reputation effects, China's financial institutions can become powerful partners in standards enforcement.

11- Pursue a strategy of high transparency with regard to project implementation, using the reputation lever to ensure standard-adherence by Chinese companies. Guinea has a spectrum of naming-and-shaming instruments at its disposal to enforce regulation vis-à-vis Chinese counterparts. Positive reinforcement of standard-adherence through public acknowledgement can complement Guinea's approach to Chinese construction firms.

12- Demonstrate feasibility of localized renewable energy solution through pilot projects. Successful pilot projects would demonstrate the feasibility of renewable energy solutions and thereby increase the political incentives for creating a comprehensive regulatory framework. At the same time, pilot projects can serve to create the experience and technological expertise necessary for the roll-out of a more comprehensive localized renewable strategy.

13- Consider long-term investments in advanced manufacturing capabilities and human capital to prepare for the potential emergence of a renewable energy equipment industry. In light of Guinea's economic trajectory and ability to draw significant outside investments to its manufacturing sector, its political leadership might consider creating domestic renewable energy equipment manufacturing in the long-term. Preparations for such a long-term strategy would entail investments in advanced manufacturing capabilities and specialized human capital. However, the potential and feasibility of this strategy will have to be assessed in great detail before taking corresponding steps.

\subsection{Suggestion for Future Research}

Based on the conclusions above, this study suggests further research structured around the following areas:

First, the literature on China's cooperative relations with Africa; is generally characterized as a resource intensive exploiter and the same time Africa as a helpless victim. In this case, it would be wonderful to measure the effect of Chinese OFDI on Guinean development, or secondly, Impact of Chinese OFDI on Domestic Investment in Guineawhether Chinese OFDI complements (crowds-in) rather than substitutes (crowds-out) local investment, an even more interesting angle for Chinese researchers would be the performance of Chinese companies in Guinea based on the Bertrand's SCP (Structure, Conduct, and Performance) paradigm.

\section{Acknowledgements}

The authors would like to take this opportunity to thank the colleagues for their priceless assistance in improving this research. In addition, they are grateful to Shadraque Mulijo Wasike and Southeast University for providing full support to this research.

\section{References}

A. J. Khadaroo. (2008). Transport infrastructure and foreign direct investment. Journal of International Development. http://dx.doi.org/10.1002/jid.1506

Aizenman, J. (1994). Foreign Direct Investment, Employment Volatility and Cyclical Dumping. NBER Working Paper No. w4683, University of California, Santa Cruz.

Asiedu, E. (2001). On the determinants of foreign direct investment to developing countries: is Afric Investment. The Manchester School Supplement, 65, 94-117. Elsevier Science .University of Kansas, USA. 
Asiedu, E. (2002). Aggressive Trade Reform and Infrastructure Development: A Solution to Africa's Foreign Direct Investment Woes. Mimeo, Department of Economics, University of Kansas.

Asiedu, E. (2002, January). On the Determinants of Foreign Direct Investment to Developing Countries: Is Africa Different? World Development. http://dx.doi.org/10.1016/S0305-750X(01)00100-0

Berthelemy, Jean- Claude. (2011). China's Engagement and Aid Effectiveness in Africa, Series $\mathrm{N}^{\circ} 129$, African Development Bank, Tunis, Tunisia.

Bhattacharya, A., Montiel, P., \& Sharma, S. (1997, June). How can Sub-Saharan Africa attract more Private Capital Inflows? Finance \& Development, 34(2).

Billington N. (1999). The Location of Foreign Direct Investment: An Empirical Analysis. Applied Economics, 31, 65-76. http://dx.doi.org/10.1080/000368499324561

Blomstrom, M., Lipsey, R., \& Zegan, M. (1994). What Explains Developing Country Growth? Working Paper No. 4132. National Bureau for Economic Research, Cambridge, Massachusetts.

Borensztein, E., J. De Gregorio, \& J.W. Lee. (1998). How Does Foreign Direct Investment Affect Economic Growth? Journal of International Economics, 45, 115-135. http://dx.doi.org/10.1016/S0022-1996(97)00033-0

Bräutigam, D. (2010, January). Africa's Eastern Promise: What the West can Learn from Chinese Investment in Africa. Foreign Affairs.

Buckley, P.J., \& Casson, M.C. (1976). The Future of the Multinational Enterprise. Homes \& Meier: London.

Caves, R.E. (1996). Multinational Enterprise and Economic Analysis (2nd ed.). Cambridge: Cambridge University Press.

CGFS. (2003, March). Financial Sector FDI in Asia: Brief Overview. Bank of Japan Journal.

Chantal Dupasquier \& Patrick N. Osakwe. (2005, September). African Trade Policy Centre Work in Progress No. 21 Economic Commission for Africa Foreign Direct Investment in Africa: Performance, Challenges and Responsibilities.

Cheng, L. K., \& Zhao, H. (1995). Geographical Patterns of Foreign Direct Investment in China: Location, Factor Endowments, and Policy Incentives. Department of Economics, Hong-Kong University of Science and Technology.

Cheng, Leonard K., \& Kwan, Yum K. (2000). What Are the Determinants of the Location of FDI? The Chinese $\begin{array}{lllll}\text { Experience. Journal of International } & \text { Economics, } & 51, & 379-400 .\end{array}$ http://dx.doi.org/10.1016/S0022-1996(99)00032-X

Climate Focus. (2011). Towards an Energizing Partnership? Explaining China's Role as a Catalyst of Renewable Energy Development in Africa. WWF, Washington DC. USA.

Cushman, D.O. (1985). Real Exchange Rate Risk, Expectations and the Level of Direct Investment. A Review of Economics and Statistics, 67(2), 297-308. http://dx.doi.org/10.2307/1924729

Davies K. (2010). Outward Foreign Direct Investment from China and its Policy Context. Columbia FDI Files. Vale Columbia Centre on Sustainable International Investment.

Duanyong, W. (2011). China's Overseas Foreign Direct Investment Risk 2008-2009. China in Africa Project, South African Institute of International Affairs, 2011.

Dunning, J. H. (1973). The Determinants of International Production. Oxford Economic Papers No. 25.

Dunning, J. H. (1980). Toward an Eclectic Theory of International Production: Some Empirical Tests. Journal of International Business Studies, (11). http://dx.doi.org/10.1057/palgrave.jibs.8490593

Dunning, J. H. (1988). The Eclectic Paradigm of International Production: A Restatement and Some Possible Extensions. Journal of International Business Studies, (19), spring. http://dx.doi.org/10.1057/palgrave.jibs. 8490372

Dupasquier, C. (2006, April). Foreign direct investment in Africa: Performance, challenges, and responsibilities. Journal of Asian Economics, 17(2). http://dx.doi.org/10.1016/j.asieco.2005.07.002

Eden, L., \& Miller, R. (2004). Distance Matters: Liability of Foreignness, Institutional Distance and Ownership Strategy. Bush School of Government and Public Service, Texas, A \& M University. 
February Wheeler, D., \& Mody, A. (1992). International Investment Location Decisions: The Case of US Firms. Journal of International Economics, 33, 57-76. http://dx.doi.org/10.1016/0022-1996(92)90050-T

Findlay, R. (1978). Relative Backwardness, Direct Foreign Investment and the Transfer of Technology: A Simple Dynamic Model. Quarterly Journal of Economics, 92, 1-16. http://dx.doi.org/10.2307/1885996

Foster, V., Butterfield, W., Chen, C., \& Pushak, N. (2008). Building Bridges: China's Growing Role as Infrastructure Financier for Sub-Saharan Africa. Trends and Policy Options.

FUE, UIA. (2011). Draft Baseline Survey of Chinese Enterprises in Uganda: Promoting Socially Responsible Business in East Africa.

Fung, K. C. et al. (2002). Foreign Direct Investment in China: Policy, Trend and Impact. International Conference on China's Economy in the 21st Century, Hong Kong, China.

Godspeeds, T. et al. (2006). Are other Government Policies more Important than Taxation in Attracting FDI? Georgia State University, Andrew Young School of Policy Study. Atlanta World development, 30(1), 107-119, 2002.

Godspeeds, T., Martinez-Vazquez, J., \& Zhang, L. (2006). Are Government Policies More Important Than Taxation in Attracting FDI. ISP Working Paper Number 06-14, International Studies Program working paper series.

Gu, J. (2009). China's private enterprises in Africa and the implications for African development. European Journal of Development Research, 21(4), 570-587. http://dx.doi.org/10.1057/ejdr.2009.21

Hanson, G. (2001). Should Countries Promote Foreign Direct Investment? G-24 Discussion Paper 9, United Nations Conference on Trade and Development (UNCTAD).

Hirschman, A. O. (1958). The Strategy of Economic Development. New Haven: Yale University Press.

Hosseini H. (2005). An Economic Theory of FDI: A Behavioral Economics and Historical Approach. Journal of Socio-Economics, 34, 530-531. http://dx.doi.org/10.1016/j.socec.2005.07.001

Jinshan, L., \& Mohan, Z. (2009). China's OFDI in the European Union as a Latecomer. Centre for European Studies, Zhejiang University.

Kindle Berger C.P. (1969). American Business Abroad. New Haven, London. The International Executive, 11, 11-12. http://dx.doi.org/10.1002/tie.5060110207

Kojima, K., \& Osawa, T. (1984). Micro and Macro-economic Models of Foreign Direct Investment: Toward a Synthesis. Hittosubashi Journal of Economics.

Kwang, J., \& Singh, H. (1996). The Determinants of Foreign Direct Investment in Developing Countries. Transnational Corporations, 5(2), 67-105.

Leonard K., \& Zihui M. (2007). China's Outward FDI: Past and Future. National Bureau of Economic Research, Cambridge.

Lipsey, R. (2002). Home and Host Country Effects of FDI. Lidingö, Sweden. Paper for ISIT Conference on Challenges to Globalization.

Liu, X. (2001, August). The impact of foreign direct investment on labour productivity in the Chinese electronics industry. International Business Review. http://dx.doi.org/10.1016/S0969-5931(01)00024-5

Mwilima. N. (2003). Foreign Direct Investment in Africa. Labor Resource and Research Institute. Social Observatory Pilot Project - final Draft Report - FDI.

Noorbakhsh, F., Paloni, A., \& Youssef, A. (2001). Human Capital and FDI Inflows to Developing Countries: New Empirical Evidence. World Development, 26(7), 1593-1610. http://dx.doi.org/10.1016/S0305-750X(01)00054-7

OECD and OCDE. (2000, April). Main Determinants and Impacts of Foreign Direct Investments on China's Economy. Working papers on International Investments. China

Onyeiwu, S., \& Shrestha, H. (2004). Determinants of Foreign Direct Investment in Africa. Journal of Developing Societies, 20, 89-106. http://dx.doi.org/10.1177/0169796X04048305

Overseas Developing Institute. (1997). Foreign Direct Investment Flows to Low-Income Countries: A Review Of The Evidence. Briefing paper. 
Pain, N. (1997). Continental Drift: European Integration and the Location of UK FDI. The Manchester School, 65(Supplement), 94-117. http://dx.doi.org/10.1111/1467-9957.65.s.5

Panitchpakdi, Supachai. (2010, August). World Investment Report 2010: investing in a low-carbon economy (overview): key messages: FDI trends. Transnational Corporations, Big5.fmprc.gov.cn /

Profil de la Guinée, Investir en Guinée, Guinée: Pays aux ressources multiples, pays d'avenir... Organisation des Nations Unies pour le Développement Industriel.

Ramkishen, S. R., \& Rabin, H. (2009). Understanding Bilateral Foreign Direct Investment Flows in Emerging Asia. Institute of South Asian Studies, University of Singapore. ISAS Insight No 81.

Rockefeller Foundation, Centre for Chinese Studies. (2010). Evaluating China's FOCAC Commitments to Africa and Mapping the Way Ahead. University of Stellenbosch.

Rudaheranwa, N. (2004). Trade Policy and Transport Costs: How EU Aid Can Promote Export Growth in East Africa. EPRC, Makerere University, Kampala.

Russ, K. (2009). The New Theory of Foreign Direct Investment: Merging Trade and Capital Flows. International Finance Journal, 12(1), 107-119.

Schneider, F., \& Frey, B. (1985). Economic and Political Determinants of Foreign Direct Investment. World Development, 13(2), 161-175. http://dx.doi.org/10.1016/0305-750X(85)90002-6

Shaukat, A., \& Wei, G. (2005). Determinants of FDI in China. Journal of global Business and Technology I(2), UK.

Sheila, P., \& Dirk, W. (2004). Foreign Direct Investment by African Countries. Overseas Development Institute, UNCTAD meeting on FDI in Africa, Addis Abeba.

Shige Makino. (2007, July). Legitimacy and multi-level institutional environments: implications for foreign subsidiary ownership structure. Journal of International Business Studies.

Smarzynska, B. (2002). Spillovers from Foreign Direct Investment through Backward Linkages: Does Technology Gap Matter? Mimeo, World Bank.

Sohlman, S. (2009). Kinas relationer med Afrika ur ett handelsperspektiv. Stockholm: Kommerskollegium (Swedish National Board of Trade).

SOMO and Labor Resource and Research Institute (La RRI). (2001). Resolution: Foreign Direct Investment in Southern Africa. Windhoek, Namibia.

Ssenyange, E. (2010). Overview of the China-Africa Development Cooperation and the Case of Uganda. Uganda Debt Network.

Tandon, Y. (2002). Fallacies about the theory of FDIs: Its ideological and methodological pitfalls. Harare, Zimbabwe: SEATINL.

Tandon, Y. (2002). The role of Foreign Direct Investment in Africa's Human Development. Harare, Zimbabwe: SEATINI.

United Nations Conference on Trade and Development (UNCTAD). (2011). World Investment Report Series 2011. Non-Equity Modes of International Production and Development.

United Nations New York and Geneva. (2007). Asian Foreign Direct Investment in Africa. Towards a New Era of Cooperation among Developing Countries.

Vernon R. (1966). International Investment and International Trade in the Product Cycle. Quarterly Journal of Economics, 80, 190-207. http://dx.doi.org/10.2307/1880689

Wheeler, D., \& Mody, A. (1992). International Investment Location Decisions: The Case of US Firms. Journal of International Economics, 33, 57-76. http://dx.doi.org/10.1016/0022-1996(92)90050-T

Yin-Wong Cheung. University of California, Santa Cruz Jakob de Han De Nederlandsche Bank Xing Wang Qian SUNY, Buffalo State College Shu Yu University of Groningen China's Outward Direct Investment in Africa This Version: October 2010.

\section{Internet Sources}

econ.hunter.cuny.edu /Fri Oct 21, 2011

etd.lsu.edu / Fri Nov 02, 2012 
ftp.iza.org / from Sat Mar 15, 2008

http://www.bubah.com/10/03/2012.03:50

http://www.cia.gov/library/publications/the-worldfacebook/gv.htm09/21/2012;10:08

http://www.doingbusiness.org/data/exploreeconomies/gunea. Htm08/21/2012; 09:18

http://www.economywatch.com/foreign-direct-investment/determinants.html/06/25/2012; 21:08 www.intexatu.com htm06/25/2011; 21:30

http://www.guinee58.com10/03/2012.03:10

http://www.guineenews10/03/2012.02:40

http://www.nationencyclopedia.com/Africa/Guinea-Foreign-Investment.htmI\#ixzz1 gnup6600.Htm07/25/2012;03:45

icevis.pau.edu.tr / Fri Jun 19, 2009

infoscience.epfl.ch / Mon Jan 21, 2008

law.hku.hk / Tue Jan 12, 2010

nai.diva-portal.org / Thu Nov 24, 2011

people.ku.edu / Sat Apr 11, 2009

people.ku.edu/ Fri Sep 09, 2011

pnet.dosie.ru / Tue Jun 17, 2008

r0.unctad.org / Thu Oct 15, 2009

wlv.openrepository.com / Wed Feb 01, 2012

www.aercafrica.org /Wed Nov 25, 2009

www.africaneconomicoutlook.org

www.africaneconomicoutlook.org Guinea 2012. Htm07/15/2012; 03:08

www.angolainc.com / Mon Nov 28, 2011

www.bou.or.ug/ Mon Jun 26, 2006

www.bul.unisi.ch / Sun Aug 01, 2010

www.buyusainfo.net / Mon Oct 24, 2011

www.city.ac.uk / Tue Nov 02, 2010

www.diakonia.se /Sat Mar 31, 2012

www.dtic.mil / Wed May 06, 2009

www.ejist.ro / Sat Oct 11, 2008

www.encyclopedia.com/ Thu Mar 24, 2011

www.encyclopedia.com/ Tue Mar 16, 2010

www.erudit.org / Wed May 16, 2012

www.gtkp.com / Sat Oct 27, 2012

www.haelaranch.com / Sun Feb 19, 2012

www.iie.com /Mon Apr 16, 2012

www.imf.org / Thu Jul 03, 2003

www.investasiapacific.com / Publications "Chapter II: Regional trends IN FDI.", World Investment Report, Annual 2010 Issue / Tue Jun 26, 2012

www.iss.co.za Tue/ Jul 20, 2010

www.iss.nl / Wed Oct 27, 2010

www.issafrica.org / Mon May 10, 2010

www.jsd-africa.com/ Nov 01, 2010 
www.mbendi.co.za/ Thu Dec 20, 2007

www.mbendi.com/ Mon Jun 28, 2010

www.nationsencyclopedia.com / Fri Oct 31, 2008

www.rgemonitor.com / Fri Jun 01, 2012

www.state.gov/ Tue Nov 02, 2010

www.trade.gov.mw/ Wed May 19, 2010

www.unctad.org / Mon Apr 02, 2012

www.unctad.org/ Sat Jun 23, 2012

www.uneca.org/ Thu Aug 02, 2012

www.uscc.gov / Wed Jan 06, 2010

www.usimr.org/ Thu May 21, 2009

www.voltairenet.org/ Tue Oct 19, 2010

www-mofa.mofa.go.jp/ Wed Feb 24, 2010

Notes

Note 1. According the UNCTAD, FDI/TNC database (www.unctad.org/fdistatistics).

Note 2. TableI.5, page 19 de CNUCED (2007).

Note 3. $\mathrm{Y}=(\mathrm{FDI}$ : Foreign Direct Investment $) ; \mathrm{X}=(\mathrm{TV}$ : Trade Volume $) ; \mathrm{Z}=\left(\mathrm{GDP}_{\mathrm{C}}\right.$ : Gross Domestic Product China); $\mathrm{W}=\left(\mathrm{GDP}_{\mathrm{G}}\right.$ : Gross Domestic Product Guinea; $\mathrm{T}=($ Employment $) ; \mathrm{V}=($ Openness $)$. 